\title{
JOSÉ VERÍSSIMO E A PROPOSTA DA GEOGRAFIA PÁTRIA NA PRIMEIRA REPÚBLICA BRASILEIRA VISTA ATRAVÉS DOS PROGRAMAS DE GEOGRAFIA DO GYMNASIO NACIONAL
}

\author{
MÔNICA SAMPAIO MACHADO* \\ Universidade do Estado do Rio de Janerio
}

Nos últimos vinte anos, a partir da realização do Congresso da Associação dos Geógrafos Brasileiros, em Fortaleza, em 1978, ressurgem na Geografia brasileira temáticas e estudos vinculados à história do pensamento geográfico. Nesse Congresso foram introduzidas mudanças cruciais, que afetaram a prática dos geógrafos e dos professores universitários no Brasil. Essas mudanças estavam associadas ao movimento de renovação vivido pela geografia em função do processo de redemocratização do país. A "abertura" política promovia a necessidade de restabelecer as discussões sobre o papel da disciplina e de recuperar sua história.

Desde então alguns esforços têm sido registrados para a organização de pesquisas, abarcando a história e a memória da geografia brasileira. Temas relativos ao seu período institucional, que teve início da década de 1930, quando surgem os Cursos de Geografia com a implantação da Universidade de São Paulo, em 1934, e da Uni- 
versidade do Distrito Federal, em 1935, aparecem com maior freqüência. Já a realização de investigações envolvendo o período pré-institucional tem sido dificultada em virtude, primeiramente, da falta de tradição da Geografia no trato das questões historiográficas e, em segundo lugar, da ausência da identificação de quais discursos poderiam ser qualificados na categoria de geográfico, visto que são desconhecidos os "geógrafos" antes da plena institucionalização da geografia no país. Seriam eles os viajantes europeus que participaram de expedições científicas no período colonial e imperial? Seriam bacharéis de Direito leitores de Ratzel? Ou engenheiros geógrafos saídos da escolas politécnicas? Ou ainda os engenheiros militares envolvidos com o levantamento cartográfico das zonas de fronteira? Ou os professores de geografia dos liceus?

Não pretendendo entrar no mérito dessa discussão, mas somente apresentar uma pequena contribuição à história pré-institucional da geografia brasileira, o trabalho ora proposto irá utilizar como fonte de estudo a obra de um dos mais importantes intelectuais do final do século XIX, o crítico literário José Veríssimo de Dias de Matos - A Educação Nacional. Publicada em 1890, primeiro ano do regime republicano, foi a mais representativa e importante obra da vertente pedagógica do autor.

Desde o final do Império, a discussão em torno dos assuntos educacionais vinha se dando de forma vigorosa. Demandava-se a tomada de posição diante das precárias condições do sistema escolar então existente e a formulação de uma política nacional de educação. A República proclamada recebe do Império uma herança caracterizada pelo fervor ideológico e pela sistemática tentativa de evangelização e redenção do país através das idéias de democracia, federação e educação. Recebe como herança um acervo rico para pensar e repensar uma doutrina e um programa de educação .

José Veríssimo, pertencendo a "geração modernista de 1870", destacando a ciência e a cultura como elementos fundamentais de construção da nação, irá propor nessa obra uma saída para a redenção do país com a construção de uma verdadeira educação nacional. Como pedras angulares desse projeto, Veríssimo enfatiza a importância de organização e implementação da História Pátria e da Geografia Pátria no Brasil. Para o autor ambas ocupavam lugar de destaque e permitiam a cristalização da tão almejada identidade nacional.

Partindo dessas considerações, dois são os objetivos deste trabalho: analisar a proposta de implantação da Geografia Pátria para a Primeira República brasileira, apresentada por Veríssimo em $\boldsymbol{A} \boldsymbol{E}$ ducação Nacional e investigar a repercussão dessa proposta no contexto nacional, entre os anos de 1892 e 1912, através do exame dos conteúdos programáticos ministrados no Gymnasio Nacional, estabelecimento

\footnotetext{
'Antônio C. R. Moraes, geógrafo com expressiva produção dedicada às pesquisas sobre história e metodologia da geografia brasileira, tem chamado atenção para as dificuldades no reconhecimento dos discursos geográficos (MORAES, 1999, p. 22).

NAGLE, 1997, p.261-262.
} 
padrão de ensino oficial no Brasil à época ${ }^{3}$. Para tanto, o trabalho está dividido em quatro partes. Na primeira, utilizando informações "biobibliográficas", procuro apresentar a importância intelectual de José Veríssimo, assim como situá-lo no cenário cultural brasileiro da época. A segunda parte é dedicada à apresentação da Educação Nacional e da Geografia Pátria. A terceira, ao Gymnasio Nacional e aos programas de geografia. E, por fim, a quarta parte é dedicada à análise desses programas à luz das propostas de Veríssimo.

\section{José Veríssimo Dias de Matos}

José Veríssimo Dias de Matos (Óbidos, Pará, 1857 - Rio, 1916) é filho de José Veríssimo de Matos ${ }^{4}$, médico militar da Colônia Militar em Óbidos, Pará, e de Anna Flora Dias de Matos. Para dar início ao curso primário, José Veríssimo, aos oito anos de idade, em 1865, segue para Manaus, hospedando-se na casa do Tenente Coronel Inocêncio de Araújo, amigo de seu pai. No ano seguinte, em 1866, junto com os pais, muda-se para Belém, onde estuda durante três anos no Seminário Episcopal. Aos doze anos, em 1869, chega sozinho ao Rio de Janeiro e hospeda-se na casa de seu tio, o advogado Conselheiro Antônio Veríssimo de Matos.

Frequienta o Imperial Collegio de Pedro $\mathrm{II}^{5}$, em seguida o Colégio Vitório e, por fim, para se dedicar à engenharia, a Escola Central. Com problemas de saúde, cursa apenas o primeiro ano, cancelando a matrícula e regressando ao Pará em 1876, com dezenove anos. No Pará participa de uma excursão, realizada pelo Governador José Lustosa da Cunha Paranaguá, ao interior da bacia Amazônica, permitindo-lhe ampliar o conhecimento acerca da realidade histórico-espacial amazonense. Emprega-se na Companhia de Navegação do Amazonas e, posteriormente, por concurso, ingressa na Secretaria do Estado. Paralelamente começa a publicar contos, críticas literárias e impressões de viagens, juntamente com escritores e redatores de notoriedade reconhecida, nos jornais de renome da Província.

Em 1881, aos vinte e quatro anos, viaja para a Europa, objetivando cuidar da saúde e participar do Congresso Literário Internacional, em Lisboa. Lá recebe a Comenda da Ordem de Cristo, com a apresentação da memória sobre o movimento

\footnotetext{
${ }^{3}$ A idéia de analisar a obra A Educação Nacional de José Veríssimo e estabelecer uma relação com os currículos do "Pedro II" partiu do Professor José Murilo de Carvalho como sugestão para elaboração do trabalho final de seu curso, Pensamento Político e Social no Brasil, segundo semestre de 2000.

Conforme biografia encontrada em Estudos Amazônicos de José Veríssimo, José Veríssimo de Matos, pai de José Veríssimo Dias de Matos, deu a seu filho o prenome de José Clemente, em homenagem ao estadista da Independência, José Clemente Pereira. Somente mais tarde, por admiração ao pai, resolve substituir o nome de Çlemente por Veríssimo. Na vida literária e entre amigos era o nome reduzido, José Veríssimo, que usava.

Segundo VECHIA, Ariclê e LORENZ, Michael Karl (p. 1998), no decreto de fundação do Colégio Pedro II consta, no artigo $2^{\circ}$, a denominação do Colégio como Collegio de Pedro II. No primeiro regulamento, de 1838 ; constam os estatutos para o Collegio de Pedro Segundo, porém, em vários documentos, inclusive nos programas de ensino, aparece, até 1890, a denominação de Imperial Collegio de Pedro II.
} 
literário no Brasil. Em 1883, retorna ao Pará, voltando a colaborar com jornais provincianos. Cria neste mesmo ano, entusiasmado com assuntos educacionais, a Sociedade Paraense Promotora da Instrução. Em 1884, funda o Colégio Americano, o qual dirige até 1890, introduzindo no Brasil a Educação Física e o Jardim da Infância. No mesmo ano casa-se com a professora Maria Elói Tavares. Em 1886, organiza, juntamente com Lauro Sodré, o Clube Republicano do Pará.

Em 1889, realiza sua segunda viagem à Europa, para participar do Congresso de Antropologia e Pré-História em Paris, apresentando a tese $O$ homem do Marajó e a antiga civilização amazônica. Em 1890, é nomeado, no Governo Interino de Paes de Carvalho, Diretor da Instrução Pública do Estado, iniciando reformas que visavam à modernização do ensino no Pará. Como Diretor da Instrução Pública inaugura, na Escola Normal, a frequiência de alunos dos dois sexos e prestigia o Museu Paraense, que, naquele momento, experimentava uma enorme decadência.

Em 1891, muda-se para o Rio de Janeiro e começa a trabalhar, a contra-gosto, em um escritório comercial. Em 1892, com a fundação do Jornal do Brasil, de Rodolfo Dantas, José Veríssimo passa a se dedicar à crítica literária e ao magistério. Entre os anos de 1892 e 1897 dirige o Externato do Gymnasio Nacional ${ }^{\circ}$. Neste período, leciona Português e História geral da América na antiga Escola Normal e rege as cadeiras de Pedagogia e de História da Instrução Pública Brasileira no Pedagogium . Em 1895, torna-se sócio fundador da Academia Brasileira de Letras, ocupando a cadeira cujo patrono é João Francisco Lisboa e da qual se afasta em 1911, por ocasião da eleição de Lauro Müller. Foi também sócio do Instituto Histórico e Geográfico Brasileiro. Em 1906, José Veríssimo se submete ao concurso para catedrático de História do Externato do Gymnasio Nacional, conseguindo o primeiro lugar perante a banca, constituída por Capistrano de Abreu, João Ribeiro e Dr. Eugênio de Barros Raja Gabaglia. Em 1910 e 1912 exerce a direção da Escola Normal, falecendo em 1916, no Engenho Novo, Rio de Janeiro.

\section{José Veríssimo: produção intelectual}

As informações biográficas sobre José Veríssimo permitem ilustrar a amplitude de sua contribuição à cultura brasileira. Jornalista, educador e crítico literário, Veríssimo buscou, a partir da incansável dedicação ao trabalho intelectual, construir, à época, um modelo brasileiro de pensamento crítico, objetivo que se evidencia na sua rica e diversificada produção intelectual.

\footnotetext{
${ }_{7}^{6}$ Segundo BARBOSA, 1985, Veríssimo chega a ser professor de Manuel Bandeira nesta Instituição.

7 O Pedagogium foi criado em 1890 por Benjamin Constant, ministro da Instrução Pública, Correios e Telégrafos, nova secretaria de Estado do regime Republicano. O Pedagogium representava o estabelecimento de ensino profissional destinado a servir como centro de aperfeiçoamento de professores públicos e particulares e centro propulsor da reforma da instrução do país (ANDRADE, 1999, p.58).
} 
Os vários escritos publicados por Veríssimo constituem obras exemplares. Essas obras podem ser agrupadas em duas fases de sua vida ${ }^{8}$. A primeira compreende livros publicados e participações como publicista e editor de periódicos da Província, entre os anos de 1878 e 1890, antes de sua mudança para o Rio de Janeiro. A segunda fase tem seu começo em 1891, quando Veríssimo inicia uma atividade ininterrupta de jornalismo literário no Jornal do Brasil, no Rio de Janeiro. Nesta fase é expressiva sua participação literária na imprensa periódica da capital do país ${ }^{9}$.

No período em que vive em sua província natal, Veríssìmo dá início a sua existência de escritor. Colabora em Liberal do Pará, mais tarde, no Diário do Grão-Pará e, por fim, funda o jornal trimestral $A$ Gazeta do Norte. Contribui também na Província do Pará, em $O$ Comércio do Pará e na República, em 1883. Cria e dirige a Revista Amazônica, da qual foram publicados dez fascículos no período de março de 1883 a fevereiro de 1884. Publica os folhetos Emílio Littré, 1881, e Carlos Gomes, 1882, quatro livros Primeiras Páginas $1878^{10}$, Cenas da vida Amazônica, de 1886, a primeira série de Estudos brasileiros (1877-1885), de 1889, e A Educação Nacional, de 1890.

$\mathrm{Na}$ obra de Veríssimo, nessa primeira fase, predomina o esforço de compreender o estado intelectual e cultural do Brasil, seja através dos estudos etnográficos regionalistas, pintando cenários amazonenses, seja através dos ensaios de síntese em que busca assimilar, sob a inspiração das teorias evolucionistas e positivistas, a evolução da vida intelectual e da própria literatura brasileira, como nos ensaios A Literatura Brasileira, sua formação e destino, O Movimento Intelectual Brasileiro de 1873-83, Literatura e Homens de Letras no Brasil e Do Nacionalismo na Poesia Brasileira, todos incluídos nos Estudos Brasileiros.

Na segunda fase, no Rio de Janeiro, em virtude de sua atuação no Jornal do Brasil, em 1894, Veríssimo publica a segunda série dos Estudos brasileiros (18891893), primeiro resultado valioso para sua trajetória crítica. Ficando encarregado da edição e direção da Revista Brasileira a partir de 1895, além de dezenove volumes terem sido publicados até 1899 , nasce a idéia da fundação da Academia Brasileira de Letras, renovando o interesse do país pela cultura literária e mobilizando intelectuais de expressão. A Revista Brasileira dá também a Veríssimo não apenas a oportunidade de publicar numerosos ensaios críticos e notas bibliográficas, muitos dos quais vão compor a primeira série dos Estudos de literatura brasileira, de 1901, mas ainda uma enorme visibilidade no cenário cultural da capital do país ${ }^{11}$.

No Rio de Janeiro, Veríssimo também intensifica sua fase de produção jornalística na área da educação, destacando-se os artigos $O$ mal de nosso ensino público, $O$

\footnotetext{
${ }^{8}$ O estabelecimento de duas fases da vida e obra de José Veríssimo é apresentada pelo crítico literário e estudioso çntemporâneo de sua obra, João Alexandre Barbosa (ver Barbosa 1985 e 2001).

${ }_{10}^{9}$ BARBOSA, 2001.

${ }^{10}$ De acordo com CAVAZOTTI, 1999, Primeiras páginas constituiu o trabalho de estréia de José Veríssimo, originário de seus primeiros escritos.

BARBOSA, 2001.
} 
ensino da História na Escola Normal, O ensino municipal do Rio de Janeiro (este publicado na Revista Educação Nacional), e ainda $A$ educação em geral, A pedagogia, A educação física, divulgados pela revista Educação e Ensino ${ }^{12}$.

Além do Jornal do Brasil, Veríssimo colabora também no Jornal do Comércio, Correio da Manhã, O Imparcial, A imprensa, Debate, A Notícia, Gazeta de Notícias, nas revistas Kosmos, Renascença, Almanaque Garnier e na Revista da Academia Brasileira de Letras, resultando na publicação das seis séries dos Estudos de literatura brasileira, das três séries de Homens e coisas estrangeiras, do volume Que é literatura? e outros escritos e da - monumental - História da Literatura Brasileira: de Bento Teixeira (1601) a Machado de Assis (1908), obra póstuma, publicada no mesmo ano de sua morte, em $1916^{13}$.

Pertencendo à "geração de 1870 " ${ }^{\text {i4 }}$, herdando o novo espírito crítico e científico do período, Veríssimo destacava-se no cenário intelectual da época por colaboração efetiva no fortalecimento da educação, da literatura, do jornalismo, enfim, da cultura e da política brasileiras. Sua produção espelhava um projeto de construção do Brasil-Nação. Essa preocupação, presente de diferentes maneiras em suas obras, refletia e mesmo potencializava o debate e o pensamento intelectual daquele momento.

\section{José Veríssimo: a geração de 1870 e o ideário nacional}

Desde a extinção do tráfico negreiro, em 1850, e a decadência da economia açucareira, inicia-se um deslocamento do eixo de prestígio sócio-econômico do norte para o sul do país, gerando, como um quadro novo para a nação, os anseios das classes médias urbanas, influenciadas pelas idéias liberais, abolicionistas e republicanas. Permeadas pelo pensamento europeu positivista e evolucionista, essas idéias, a partir de 1870, introduzem-se na intelectualidade brasileira e propiciam o rompimento com a então visão romancesca, típica do século XIX. Comte, Taine, Spencer, Darwin e Haeckel tornam-se autores referências desta nova geração de intelectuais nacionais, a chamada "geração modernista de 1870".

Começando a escrever por volta de 1875-1880, a "geração de 1870", orientada pelas influências de Tobias Barreto e a Escola de Recife, afirmava o novo espírito crítico, aplicando-o aos diferentes aspectos da realidade brasileira. Desta geração destacam-se Capistrano de Abreu, no desenvolvimento da História, Sílvio Romero, desdobrando-se sobre as letras, a etnografia, o folclore e a teoria da cultura, Araripe

\footnotetext{
${ }_{12}^{12}$ CAVAZOTTI, 1999.

${ }_{14}^{13}$ BARBOSA, 1985 e BARBOSA, 2001.

"A "geração de 1870" (também conhecida como "geração ilustrada", pela seu esforço em iluminar o país através da ciência e da cultura, ou como mosqueteiros-intelectuais), captou o significado das transformaçōes em curso. denominando-as de modernismo. Essa mesma geração é a responsável pela construção do pensamento moderno sobre a nação brasileira, pensamento que assume a dianteira nos debates intelectuais a partir de 1920 (Ver Lúcia L. Oliveira, 1990, p.80).
} 
Júnior e José Veríssimo, ambos voltados intensamente para a crítica sócio-literária $^{15}$.

Influenciados pelas filosofias da história centradas no determinismo geográfico e racial revestidas de um sabor cientificista e modernizador, esses intelectuais buscavam pensar a integração do Brasil na cultura ocidental. Consideravam prioritário, para a realização desta integração, o desenvolvimento da cultura e da ciência. Somente o poder das idéias, a confiança total na ciência e a certeza da importância da educação intelectual constituíam caminhos legítimos parà melhorar os homens e atualizar o país, superando o atraso cultural e acelerando sua marcha evolutiva ${ }^{16}$. A construção do Brasil como uma nação moderna era meta essencial dessa intelectualidade assim como a formação do sentimento brasileiro. A nacionalidade era tomada como critério básico e indispensável de avaliação dos produtos literários, científicos e culturais brasileiros.

Como o modelo de edificação do Brasil moderno foi buscado nas grandes nações imperiais européias, os intelectuais brasileiros se deparavam com problemas semelhantes, no que se refere à instauração do Estado brasileiro moderno: a ausência de uma nação e de um Estado forte. A construção da nação e a remodelação do Estado foram dois parâmetros essenciais da produção intelectual daquele momento, produção que tinha como finalidade atualizar o Brasil frente ao exemplo político-cultural europeu e americano ${ }^{17}$.

Não obstante essa idéia de construção da nação só tenha começado a tomar expressão no meio intelectual nos anos de 1870 , ela não era nova. Sua constituição já se fazia presente na elite imperial desde 1820 , principalmente entre os políticos brasileiros que lideraram o processo de independência, muito embora, até 1870 , esse mesmo sentimento de identidade nacional estivesse ausente entre os grupos locais e na população em geral. Nas províncias, até a década de 70, transpareciam ressentimentos contra o Imperador, a Corte e o Rio de Janeiro, e nenhuma preocupação era registrada com relação à manutenção da unidade nacional. A palavra pátria apre-

\footnotetext{
${ }^{15}$ Desta geração, poderiam ser listados ainda os nomes de Clovis Bevilacqua, Lafayette Rodrigues Pereira e Pedro Lessa, juristas de sólida doutrina e gosto pelo fenômeno literário; Miguel Lemos e Teixeira Mendes, defensores do positivismo como doutrina; Joaquim Nabuco e Rui Barbosa, exprimindo majestosamente a vida social brasileira dos fins do século XIX e dela participando não só como escritores, mas também como grandes homens públicos, de caráter liberal. Alimentados também por essa cultura, embora transcendendo-a em certos aspectos, destacam-se João Ribeiro, Euclides da Cunha, Alberto Torres, Oliveira Viana e Manoel Bonfim (BOSI, 1994. p. 245-259).

Para essa geração de intelectuais, o fluxo europeu era a verdadeira, única e definitiva tábua de salvação, capaz de selar de uma vez a sorte de um passado obscuro e vazio de possibilidades, e de abrir um mundo novo, liberal, democrático, progressista, abundante e de perspectivas ilimitadas, como se prometia. A palavra de ordem da geração modernista de 1870 era condenar a sociedade fossilizada do Império e pregar as grandes reformas redentoras: a abolição, a república, a democracia. Toda essa elite europeizada foi responsável pelos fatos que mudaram o cenário político, econômico e social brasileiro: eram todos abolicionistas, todos liberais democratas e praticamente todos republicanos (só Nabuco não era republicano, embora fosse um liberal progressista), todos trazem como lastro de seus argumentos as novas idéias européias e se pretendem os seus difusores no Brasil (SEVCENKO. 1999, p.79)

SEVCENKO, 1999, p.83.
} 
sentava-se de forma ambígua, sendo usada com freqüência para denotar províncias e não Brasil. É somente a partir da guerra contra o Paraguai (1865-1870) que a nação inteira se mobiliza, demonstrando a população pela primeira vez um sentimento positivo de pátria brasileira. A poesia, os cartuns e o próprio governo passam também a atestar de forma efetiva esse sentimento patriótico ${ }^{18}$.

A "geração de 1870", imersa nesse fluxo de acontecimentos e influenciada pelo pensamento europeu positivista, acaba conduzindo a dianteira do debate sobre a definição e a construção da nacionalidade. Políticos, jornalistas, cronistas e escritores, espantados com o ritmo com que as grandes potências retalhavam o globo terrestre nas últimas décadas do século XIX e temerosos de que o Brasil viesse a sofrer uma invasão das potências expansionistas, perdendo sua autonomia ou parte do seu território, passam a veicular em seus discursos e produções literárias posições tanto de alarme quanto de defesa da nação. Como uma maneira de aprofundar o conhecimento sobre o Brasil, essa geração dedica-se à realização de estudos sobre os diversificados aspectos da realidade brasileira, fortalecendo o já evidente nacionalismo intelectual ${ }^{19}$.

Embora propondo-se a refletir e elaborar o novc pensar no e sobre o Brasil, esses "mosqueteiros-intelectuais" encontraram um país surdo e preguiçoso à campanha de salvação e construção nacional. O advento concatenado da Abolição em 1888 e da República em 1889, com a promessa de democratização, significou ironicamente experiência mais traumática e desagregadora dessa geração. Foi uma verdadeira decepção que pairou sobre essa elite intelectual modernizadora ${ }^{20}$.

A agitação política dos primeiros anos da vida republicana conduz ao afastamento de muitos intelectuais da arena política. Entre 1890 e 1900, um grande número de escritores abandona uma posição de engajamento na vida social para defender uma posição de ceticismo e distanciamento em frente da estrutura política, social e econômica do país. José Veríssimo, destacado intelectual desta geração, que de sua coluna no Jornal do Comércio praticamente dirigia todo o movimento literário na primeira década do século XX, descrevia essa decepção com freqüência e clareza, salientando o pessimismo e o inconformismo que permeavam os debates do período.

\footnotetext{
${ }_{18}^{18}$ CARVALHO, 1999a, p.233-268.

${ }_{20}^{19}$ SEVCENKO, 1999, p. 83-85.

${ }^{20} \mathrm{O}$ desapontamento com o advento da República parece não ter sido sentido apenas pela intelectualidade brasileira. Conforme José Murilo de Carvalho (1999b, p.37), diferentes foram os setores da sociedade nacional atingidos pela mudança do sistema de governo, naquele momento. "A expectativa inicial, despertada pela República, de maior participação, foi sendo assim sistematicamente frustada. Desapontaram-se os intelectuais com as perseguições do governo Floriano, desapontaram-se os operários, sobretudo sua liderança socialista, com as dificuldades de se organizarem em partidos e de participarem do processo eleitoral; os jacobinos foram eliminados. Todos esses grupos tiveram de aprender novas formas de inserção no sistema, mais fáceis para alguns, mais dificeis para outros. Os intelectuais desistiram da política militante e se concentraram na literatura, aceitando postos decorativos na burocracia, especialmente no Itamaraty de Rio Branco".
} 


\section{A educação nacional}

"Pois bem, forçosamente republicano, não porque acredite na efficacia e infallibilidade da republica, da qual vejo apenas uma resultante e não um factor, uma formula governamental mas não a fórma definitiva que ainda escapa às nossas previsões, porém por julgá-la determinada pelas nossas circunstâncias politicas e evolução historica, é sinão com honestidade, ao menos sem nenhuma sympathia que encaro o atual movimento republicano, fadado por ventura a não remoto triumpho." (JOSÉ VERÍSSIMO, 1890)

Foi na passagem da Monarquia para a República, em clima de euforia e, ao mesmo tempo, de desilusão com a implantação do novo sistema de governo, que Veríssimo escreve $A$ Educação Nacional. Elaborada a partir de uma crítica devastadora ao sistema educativo de então, essa obra vinha propor explicitamente uma contribuição às mudanças que deveriam surgir com o regime republicano. A primeira edição foi publicada no Pará, em 1890, logo após a proclamação da República e a implementação da reforma na área educacional, levada à frente por Benjamin Constant, então ministro da nova Pasta da Instrução Pública ${ }^{21}$. A segunda edição foi publicada no Rio de Janeiro, em 1906, pela livraria Francisco Alves ${ }^{22}$. Nesta reedição, o autor inclui uma extensa introdução, apresentando um balanço extremamente crítico das primeiras medidas executadas pela administração de Benjamin Constant.

Veríssimo inicia a introdução da primeira edição de A Educação Nacional, sob uma posição cética com relação ao tipo de República implantada no país. Como a República brasileira havia se estruturado a partir da simples mudança da forma de governo, desconsiderando o elemento povo, único que poderia mudar radicalmente a nação, Veríssimo não dava crédito à proposta republicana brasileira de regenera-

\footnotetext{
${ }^{21}$ A Instrução Pública, no período imperial, ficava ao cargo do Ministério do Império (1808-1891). Esse Ministério, com a Declaração do Governo Provisório Republicano de 15 de novembro de 1889, altera sua denominação para Ministério do Interior. Pelo Decreto 346 de 19 de abril de 1890, fica criado o Ministério da Instrução Pública, Correios e Telégrafos, que recebe os serviços relativos à instrução pública, aos estabelecimentos de educação e ensino especial ou profissional, aos institutos, academias e sociedades que se dedicassem às ciências, letras e artes, até então a cargo do Ministério do Interior. Recebeu também serviços relativos aos Correios e Telégrafos que faziam parte do Ministério da Agricultura, Comércio e Obras Públicas. Entretanto foi extinto pela Lei 23 de 30 de outubro de 1891, que reorganizou os serviços da administração Federal. Com a extinção do Ministério da Instrução Pública, parte de suas atribuiçōes vai para o Ministério do Interior, Viação e Obras Públicas e parte vai para o Ministério da Justiça e Negócios Interiores (fonte: Guia de Fundo do Arquivo Nacional). Assim, o novo regime republicano cria um ministério para a instrução pública que logo deixa de existir, sendo transformado em mera diretoria do Ministério da Justiça e Negócios Interiores. Tal fato indica que a República não estabelece uma política diferente da política imperial no que se refere à instrução pública, esta acaba também não se constituindo como um dos empreendimentos prioritários na construção e definição da nação republicana.

Esta obra contou ainda com uma terceira edição em 1985, data da implantação da Nova República, o que vem demonstrar a importância e a atualidade das questōes nela tratadas. Esta terceira edição conta com o prefácio do crítico literário João Alexandre Barbosa.
} 
ção do país ${ }^{23}$. Para ele, a transformação absoluta do Brasil se efetivaria a partir do povo. Somente a reforma e a restauração do povo, da nação, poderiam levar à transformação e construção de um Brasil moderno. Para tanto, Veríssimo julgava existir um só meio infalível, certo e seguro - a educação.

"Nós tivemos já a reforma radical no governo, cumpre-nos completar a obra da revolução pela reforma profunda da nossa educação nacional ${ }^{.24}$.

Para a implantação da reforma da educação nacional, Veríssimo considerava fundamental a construção e o fortalecimento de um sentimento que o povo brasileiro não dispunha - o sentimento nacional, que para o autor, se distinguia de caráter nacional. Estabelecendo a comparação do Brasil com os Estados Unidos, Veríssimo vai desenvolvendo a diferenciação de caráter e sentimento nacional.

No Brasil, graças à unidade de raça, formada pelo cruzamento do índio, português e negros, à unidade da língua e da religião, enfim, graças às influências das tradições portuguesas, o caráter nacional era, incontestavelmente, mais intenso do que nos Estados Unidos, onde, segundo Veríssimo, tal caráter era inexistente pois os elementos étnicos e sociais eram muito diversos e desencontrados: havia o alemão, o saxônio, o luterano ou evangélico, o inglês, angìo-saxônio, presbiteriano ou anglicano, o irlandês, o celto-bretão, o católico, além do francês, do negro e do holandês, sem contar com o índio e o chinês, quase eliminados. Cada ụm guardava sua língua ou dialeto, e ainda sua literatura e as suas tradições. Embora o caráter nacional estivesse ausente, esse amálgama pôde produzir uma grande nação. Essa grandeza nacional, segundo o autor, era fruto da força do sentimento nacional. O contrário acontecia com o caso brasileiro.

O sentimento nacional norte-americano, segundo Veríssimo, estava alimentado por um orgulho nacional, fruto da prosperidade oriunda da extensa migração, pela abundância de excelentes terras e pelo progresso material. Já no Brasil, assinala o autor, não havia nada, desgraçadamente, de que se orgulhar. Reportando-se à observação de Sílvio Romero em História da Literatura Brasileira, Veríssimo aponta que enquanto nos outros países seus grandes homens, suas grandes obras, seus poetas, sábios, estadistas eminentes e escritores eram citados com vaidade, no Brasil a inspiração estava centrada na natureza, a qual era a base de nossa vanglória, de nosso orgulho. Expressões como o "majestoso Amazonas", as "soberbas florestas", os "rios gigantes", as "montanhas que tocam as nuvens" eram freqüentemente utilizadas nas então referências nacionais.

\footnotetext{
José Murilo de Carvalho, estudando a história da construção das imagens da nação no Brasil, estende a idéia da ausência do povo para além do período republicano: "As imagens da nação variam ao longo do tempo, de acordo com as visões da elite ou de seus setores dominantes. Desde 1822, data da independência, até 1945, ponto final da grande transformação iniciada em 1930, pelo menos três imagens da nação foram construidas pelas elites políticas e intelectuais. A primeira poderia ser caracterizada pela ausência do povo, a segunda pela visão negativa do povo, a terceira pela visão paternalista do povo. Em nenhuma o povo fez parte da construção da imagem nacional. Eram naçōes apenas imaginadas" (CARVALHO, 1999a, p.233).

VERISSIMO, 1890, p.XI.
} 
Outro elemento essencial e imprescindível para o nascimento e difusão desse sentimento patriótico, conforme Veríssimo, era a educação nacional. O povo americano depositava na escola esse papel fundamental de construção da nação. A escola norte-americana permitia, através da distribuição da mesma educação para todos os cidadãos, a ligação de seus elementos heterogêneos, elementos de raça, de religião e de costumes, permitindo, assim, a construção da verdadeira unidade do espírito americano. O mesmo não acontecia com o Brasil.

De acordo com o autor, nunca foi dada à escola brasileira a verdadeira importância social. Permanecendo isolada na esfera da instrução primária, a escola no Brasil não teve a mínima influência na formação do caráter nacional, nem no desenvolvimento do sentimento nacional. Essa falta de brasileirismo, segundo Veríssimo, era resultado da enorme e irregular extensão do país comparada com sua escassa população, isolada em localidades, primeiramente nas capitanias e depois nas províncias. Assim, os habitantes que aqui viveram estavam alheios ao país; desenvolviam-se neles o sentimento local como o de pátria: havia baianos, paulistas, paraenses, mas quase nunca o brasileiro. A falta de vias de comunicação e a carestia da população, além de contribuírem para esses localismos, impediam também a circulação pelo território e o conhecimento do país. Não só era difícil encontrar um brasileiro que tivesse, por prazer ou por instrução, viajado pelo Brasil como também, durante muito tempo Portugal, Lisboa e Coimbra representavam as capitais intelectuais do país.

Conforme Veríssimo, o desconhecimento do Brasil e o isolamento entre as províncias foram mantidos em virtude da ausência de uma organização da educação pública. Pessimamente organizada, a educação nacional não buscou jamais ter uma função integradora do espírito brasileiro. Jamais procurou, diferentemente dos Estados Unidos, ser utilizada para reduzir e atalhar o espírito local. A pátria brasileira era tratada da mesma forma como eram tratadas as outras terras, sem individualidade ou afetividade. Acrescentava-se a este fato a saída de muitas crianças brasileiras para realizarem seus estudos fora do país, as quais, ao retornarem, tornavam-se cidadãos inúteis, alheios e ignorantes à realidade da própria pátria. Nada colaborava para amenizar essa situação, nem mesmo havia, como bem denuncia Veríssimo, museus, monumentos e festas nacionais. A população brasileira, composta por um alto índice de iletrados ( $84 \%$ da população), não encontrava nada que falasse de pátria, nem mesmo a educação nacional.

Em função dessa indiferença pelas coisas nacionais, o autor salienta a pobreza da literatura nacional: o jornalismo pouco, ou raramente, ocupava-se do Brasil; revistas que divulgassem para todo o Brasil os trabalhos dos intelectuais e artistas eram inexistentes, assim como ilustrações sobre as diversas paisagens brasileiras; livros ou qualquer outro produto nacional eram mais difíceis de serem encontrados do que qualquer obra estrangeira, mesmo de origem alemã ou italiana; somente o Rio de Janeiro possuía publicação de livros e periódicos, as raras e poucas publicações nas províncias não circulavam pelo país, eram para os brasileiros como se fossem publicadas na China. Essa triste realidade, como bem ressalta Veríssimo, vinha afir- 
mar a nossa total ignorância sobre nós mesmos e a extrema pobreza, ou mesmo falta, do sentimento nacional.

Para livrar o país dessa ignorância e construir a identidade nacional, o autor propõe como principal objetivo a ser alcançado pelos estadistas brasileiros a criação da educação nacional e a difusão e exaltação da instrução pública. Ambas, instrução pública e educação nacional, permitiriam combater os espíritos separatistas, despertar o espírito da pátria e colocar acima do princípio federalista a unidade moral da nação.

Para o fortalecimento desta proposta, Veríssimo lança mão dos exemplos de regeneração nacional da França e da Itália. Nesses países a restauração nacional foi realizada através da educação pública. Na Itália foi fruto da atividade de seus escritores, poetas, publicistas, oradores e professores; resultado de um grande trabalho de uma nova educação, realizada não apenas nas escolas, mas também nas universidades, na imprensa e nos livros. A França, após a mutilação de seu território, e fundamentalmente vencida no seu orgulho pelo conflito franco-prussiano, foi para a educação pública que se voltou, enviando para a Alemanha missões oficiais, professores e pedagogos para estudarem a teoria e prática do ensino público de seu país. O mesmo ocorreu com a Inglaterra, os Estados Unidos, a Suécia, a Holanda e a Suiça. Nesses países, enfatiza o autor, a educação pública foi tratada da mesma maneira com que eram tratados os assuntos da reorganização militar.

Faltava ao Brasil esse espírito reformador. Veríssimo, em A Educação Nacional, vem defender a proposta de regeneração do país, através da implementação de uma política educacional pautada na educação nacional e na instrução pública. Como forma de fortalecimento do espírito brasileiro, já tão enfraquecido, era necessário modernizar e nacionalizar a instrução pública.

"Precisamos ser physica, moral e intellectualmente fortes, e que a Humanidade conte conosco.

Para isso porém, carecemos primeiramente ser brazileiros. $\mathrm{O}$ amor da patria alenta-se do conhecimento do seu passado, e do seu presente, e da fé no seu futuro." ${ }^{25}$

A obra de Veríssimo, na edição de 1890, contou com sete capítulos: "A Educação Nacional”; “As Características Brazileiras”; “A Educação do Carater”; “A Educação Physica”; “A Geografia Patria e a Educação Nacional”; "A História Patria e a Educação Nacional” e "O Brazil e os Estados Unidos”.

No primeiro capítulo, Veríssimo apresenta e aprofunda a situação dos três ramos, primário, secundário e superior, da educação nacional no Brasil, para demonstrar a total falta de preocupação com o conhecimento do país e a ausência, sobretudo, da educação cívica e patriótica. No segundo capítulo, o autor conclui que as características dominantes do caráter brasileiro estavam sustentadas pela indiferença, pelo desânimo, pela passividade e pela fraqueza com as coisas nacionais. Buscando com-

\footnotetext{
${ }^{25}$ VERÍSSIMO, 1890, p. XXXIV.
} 
bater o que deprimia em nosso caráter e produzir ao mesmo tempo, as qualidades contrárias, Veríssimo desenvolve o terceiro capítulo, destacando a importância da educação do caráter brasileiro como a forma mais elevada de educação nacional, elemento indispensável para os mais altos interesses de constituição da pátria brasileira. No quarto capítulo, Veríssimo defende a introdução da educação física no sistema geral de ensino brasileiro, como uma das maneiras de fortalecimento das característica físicas da nação. No quinto e sexto capítulos, o autor discorre sobre o estado em que se encontrava o ensino de Geografia e de História no Brasil e defende a necessidade de modernização desses campos de saber, uma vez que eram fundamentais para o conhecimento da história e da geografia brasileiras. Por fim, no último capítulo, o autor procura nos Estados Unidos o que de melhor pudessem apresentar como modelo de construção do sentimento e unidade nacionais. Embora reconheça a riqueza norte-americana com relação à questão nacional, Veríssimo não advoga a favor da simples cópia de seu modelo educativo. Defende o estudo aprofundado desse modelo, mas a conservação e o desenvolvimento do que nos é peculiar, da nossa originalidade brasileira, do nosso caráter nacional, dos nossos costumes e do nosso afeto com as coisas nacionais. Só assim, firmando nossas características, poderíamos conquistar nossa independência.

A segunda edição de A Educação Nacional, em 1906, contou com o acréscimo de um capítulo sobre a educação da mulher brasileira. Conforme Veríssimo, em função da nossa herança cultural ibérica havíamos herdado repugnantes tradições, como a clausura, conventos, humilhações em geral do ser feminino, confinado aos doces e às longas orações. Objetivando combater essas tradições, o autor defendia a extensão da instrução integral e enciclopédica à mulher, que deveria adquirir, assim como os homens, conhecimentos de química, língua e literatura nacionais, educação artística, geografia e história geral e do Brasil.

Além do capítulo dedicado à educação da mulher, essa reedição contou, conforme já mencionado anteriormente, com uma nova e longa introdução, intitulada: $A$ Instrução no Brazil Actualmente. Esta introdução reproduz extensamente o texto escrito pelo autor para o Jornal do Brasil, em 1892. Veríssimo manifesta abertamente a decepção com as reformas introduzidas pelo governo republicano, sobretudo através da ação de Benjamin Constant. Segundo o autor, embora Benjamin Constant fosse, além de educador, um dos fomentadores das novas instituições, ele havia sido transferido, por conveniências políticas, do Ministério da Guerra para o recém-criado Ministério da Instrução Pública, Correios e Telégrafos sem que estivesse preparado para o cargo ${ }^{26}$.

\footnotetext{
${ }^{26}$ Segundo LEMOS (1997, p. 19), Benjamin Costant foi derrotado no plano pessoal, em 1890, perdendo o Ministério da Guerra para Floriano Peixoto, considerado mais capaz de erradicar a agitação política das Forças Armadas. Como prêmio de consolação, o Governo Provisório cria para ele o Ministério da Instrução Pública, Correios e Telégrafos, que, embora afinado com sua vocação pedagógica, carecia de qualquer preocupação oficial de longo prazo com a questão educacional, tendo sido extinto pouco mais de um ano logo após sua morte.
} 
As reformas Benjamin Constant e seus muitos regulamentos acabaram não se realizando. Conforme Verísssimo, embora a reformulação da educação tenha atingido a instrução pública por completo, desde a primária do então Distrito Federal até a superior, e tenha tido o mérito de criar um movimento a favor do ensino público, um estímulo à nação pela demonstração de preocupação do novo regime com a cultura do Brasil, não havia conseguido implementar melhorias com relação à qualidade educacional.

De acordo com Veríssimo, o ensino primário continuava, assim como no Império, sob responsabilidade dos governos locais (desde o Império era de competência das províncias passando a ser reservado aos estados em que aquelas haviam se transformado com o advento da República), o que impedia a implantação de um ensino único em todo o país. Por motivos de descentralização dos ramos do ensino e como consequiência da federação, a nova reorganização do ensino secundário também não havia sido radical. Embora o Gymnasio Nacional se constituísse como estabelecimento modelo de ensino no Brasil, fixando os planos e os programas oficiais de ensino, o caráter liberal da reforma acabou delegando aos estados excessiva liberdade, colocando na mão destes a decisão de ingresso nos cursos superiores da União. $\mathrm{O}$ mesmo caráter liberal levou ao aumento da autonomia do ensino particular, autonomia de que já gozava no antigo regime, passando a ser orientado, cada vez mais, pelo puro mercantilismo.

Mesmo conhecendo de perto a indiferença dos poderes públicos com a educação, a partir não só do pessimismo promovido pela não realização das reformas propostas por Benjamin Constant, mas também pela experiência adquirida, primeiramente, na Direção da Instrução Pública no Pará e, depois, na Direção do Gymnasio Nacional, Veríssimo continuou lutando a favor da implantação e difusão de um projeto de educação nacional no Brasil.

A Educação Nacional, ao propor um novo programa para a educação brasileira, passou a ser uma referência importante no projeto de construção do Brasil-Nação. Nessa obra, a filosofia da educação, a pedagogia e a própria experiência do autor possibilitaram a formação de uma rede importante de conceitos, propostas e objetivos fundamentais, não apenas para o setor educacional em geral, mas sobretudo para a utilização da educação como fator de construção e renovação nacional. Tinha a intenção de denunciar a falta absoluta da educação nacional e apresentar uma saída para o país.

\section{A Geografia Pátria e a Educação Nacional}

Como parte da proposta de reformulação e construção do sentimento nacional por meio da educação, Veríssimo destaca o papel da Geografia Pátria e da História Pátria. Para o autor, a falta de conhecimento da geografia e da história do país demonstra o desprezo excessivo do brasileiro pelo Brasil. O fato de os estudos de 
Geografia e História do Brasil serem realizados por estrangeiros, e não por brasileiros, suscetibiliza Veríssimo, uma vez que esses conhecimentos, representavam alicerces do ensino, importantes desde os primeiros anos de instrução.

"Que desamor profundo do paiz, está este facto a revelar! Entretanto o conhecimento do paiz em todos os seus aspectos, que todos se podem resumir em dous - geographico e historico - é a base de todo o patriotismo esclarecido e previdente" ${ }^{27}$.

O desapreço pela produção e sistematização de um conhecimento histórico-espacial do Brasil, tornava sua instrução pública igual a qualquer outra desenvolvida em outro país. Na escola brasileira, inexistia o conhecimento acerca do Brasil, e o ensino compunha-se de um amontoado de matérias desconectadas entre si por uma idéia moral superior. Citando Spencer, Veríssimo sublinha a necessidade de edificação de uma idéia moral para que a educação do povo brasileiro pudesse se efetivar. Sem ela seria impossível formar um homem ou um cidadão nacional, pois a educação em uma democracia deveria ser capaz de construir tanto um negociante sagaz ou um hábil industrial, ou um poeta, ou um bacharel, quanto um cidadão consciente de sua pátria. Quem, melhor do que o próprio governo central, poderia oferecer e viabilizar esse ensino cívico e moral? Quais conhecimentos seriam imprescindíveis para a realização de tal empreendimento? Para Veríssimo o ensino de Gęografia Pátria representava uma das âncoras do processo de constituição do cidadão brasileiro, que deveria ser conduzido pelo governo central.

Entretanto, o estado de desenvolvimento da Geografia no Brasil impossibilitava a realização dessa tarefa. A Geografia no Brasil não era moderna e primava pela ausência de estudos sobre a realidade territorial do país. A modernização da Geografia, levada à frente, essencialmente, pelos europeus, havia sido marcada, principalmente, pelo trabalho de Karl Ritter, na última metade do século XIX. Com Ritter a Geografia havia passado por uma reforma radical, tanto nos seus métodos como no seu espírito, transformando-se, na expressão de Veríssimo, em uma verdadeira "psicologia da terra" "28 . Essa mudança na forma de produção do conhecimento geográfico estava longe de encontrar ressonância no Brasil.

A Geografia desenvolvida no Brasıl resumia-se à simples memorização de nomes de cidades, rios, acidentes geográficos, etc. Um conhecimento pautado na pura lógica enciclopédica sem nenhum poder explicativo. Tão distante, sublinha Veríssimo,

\footnotetext{
${ }^{27}$ VERÍSSIMO, 1890, p.102.

${ }^{28}$ Veríssimo, ilustrando a importância de Ritter, faz referência ao inglês Geikie, que em seus estudos indica superiormente a importância do moderno ensino geográfico: "Ligando as particularidades locaes com a historia humana, a geographia nota quão largamente influiram ellas sobre o progresso dos acontecimentos politicos, como por exemplo dirigiram a emigração dos povos, guiaram a onda de conquistas, moldaram o carater nacional e deram até colorido á mytologia e a litteratura nacionaes" (ARCH. GEIKIE, The Teaching Geography, Londo, 1887, p.2. - Apud.VERISSIMO 1890, p.94)
} 
estávamos dos excelentes trabalhos alemães, ingleses, americanos ou franceses como os de Levasseur e Vidal de La Blache, na França, e os de Geikie, na Inglaterra ${ }^{29}$.

Somava-se à não modernização da Geografia no Brasil, a ausência de estudos de Geografia do Brasil. Conforme Veríssimo, imperava o total desconhecimento do território brasileiro. A Geografia do Brasil era de nomenclatura. Contudo não dominavam nomenclaturas nacionais, mas sim nomenclaturas dos diversos acidentes geográficos de outros países, principalmente dos países europeus.

A Geografia Pátria era quase impossível de ser estudada pela falta completa de dados. Nos livros de leitura prevalecia a indiferença com as questões nacionais. A carência de informações espaciais e de seu respectivo material pedagógico impedia a viabilidade da formação do cidadão brasileiro. Faltavam tratados, compêndios, manuais, mapas, átlas, cartas temáticas e estudos particulares de cada grande divisão do Brasil, enfim, inexistia qualquer material capaz de mostrar com nitidez a realidade brasileira e, por conseguinte, a Geografia Pátria ${ }^{30}$. Os escritos e estudos estrangeiros que, traduzidos ou mesmo copiados, construíam e substanciavam a educação dos jovens brasileiros, eram alheios ao Brasil ${ }^{31}$. Assim, a Geografia escolar brasileira não contava com nenhum material, nem de Geografia geral nem de Geografia do Brasil, que pudesse conduzir à modernização deste conhecimento e fornecer elementos para a formação da identidade nacional.

Embora os programas de ensino tivessem sido modificados pelo governo em 1882, segundo Veríssimo essa mudança havia sido desacertada, pois introduzia na Instrução Pública da Corte, no programa do estudo de Geografia do ensino secundário, pontos que eram impossíveis de serem sustentados e incorporados pelo ensino primário. Este, por medidas de descentralização, tanto no Império quanto na República,

\footnotetext{
${ }^{29}$ Verísimo (1890, p. 100) destaca a importância da contribuição do geógrafo francês Levasseur para os modernos estudos de Geografia. A publicação intitulada Le Brésil, uma separata da Grande Encyclopédie, acompanhada por uma coleção magnífica de Vues du Brésil, para Veríssimo era exemplar, sendo a mais perfeita e completa sob vários aspectos da geografia do país, pois tratava-se de um resumo da Geografia Física, Política e Econômica, da História e dos progressos sociais do Brasil ilustrada por mapas, gravuras e gráficos. Essa obra, elaborada por Levasseur com a colaboração de brasileiros como Barão de Rio Branco e Eduardo Prado, teve sua primeira e segunda edições em 1889, apenas na língua francesa. No ano de 2000, pela Bom Texto e Letras \& Expressões, recebe sua terceira edição, a primeira edição em língua portuguesa. Le Brésil representou um modelo para os estudos geográficos à época, pois a forma com que realizou um retrato do Brasil colonial e imperial, no momento de efervescência de um Brasil republicano, era completamente nova.

${ }^{30}$ Segundo Veríssimo, raros eram os compêndios sobre as províncias. Destes compêndios somente alguns eram considerados bons, aprovados e recomendados pelos conselhos diretores da instrução pública, embora só apresentassem a enumeração seca das cidades, a indicação do bispado, a divisão judicial, o número de representantes, deixando de fora considerações sobre o clima, a configuração física, o regime das águas, os produtos e as zonas de produção. (VERÍSSIMO, 1890, p.97)

"Conforme Veríssimo, o Brasil encontrava-se obscuro na América do Sul. Havia apenas dois átlas brasileiros, o de Cândido Mendes e o de Ch. Robin, que além de conterem informações incorretas e possuírem preços elevados, não satisfaziam à cartografia da época. Com relação aos mapas murais do Brasil, o autor dá destaque ao trabalho de Levasseur, feito sob encomenda pela Instrução Primária do Rio de Janeiro e auxiliado pelo Barão de Rio Branco, um dos homens que melhor conheciam a História e a Geografia brasileiras. Entretanto este mesmo mapa era deficiente para um estudo do Brasil. Vários acidentes geográficos não estavam ali indicados, assim como faltavam os rios navegáveis e muitas cidades (VERÍSSIMO 1890, p. 99-100).
} 
havia ficado ao cargo das províncias, o que dificultava a implantação de uma proposta de ensino único para o país.

A Geografia no ensino primário continuava, mesmo depois dessa reforma, a ser lamentável, dominando a decoração e a recitação da lição. No ensino secundário, a Geografia objetivava, basicamente, os exames e resumia-se à enumeração e à nomenclatura $^{32}$. No ensino superior inexistia o estudo de Geografia. Havia, comenta Veríssimo, na Escola Politécnica do Rio de Janeiro, um curso denominado Engenharia Geógrafica, que estudava geodésia, astronomia e topografia numa estreita visão matemática e agrimensora, contudo não estudavam qualquer matéria que integrasse a então moderna ciência geográfica ${ }^{33}$.

A realidade em que se encontrava a Geografia no Brasil, exigindo modificações, chamava a atenção de Veríssimo. Para reverter essa situação, o autor sugere que imitemos os exemplos de países como França, Alemanha, Estados Unidos ou mesmo Argentina, que para fortalecerem a escala política nacional investiram maciçamente na modernização e no ensino de Geografia. Nesses países foram surpreendentes os movimentos nacionais a favor do estudo dessa matéria. Foram incentivadas e criadas sociedades topográficas e geográficas, revistas especiais, livros e cadeiras para ensino superior. Na França passaram a ser produzidos materiais geográficos para mostrar a enorme nitidez da Geografia Pátria, como tratados, compêndios, manuais, mapas murais, átlas, cartas, globos, e também diferentes cartas especiais, como geológicas, econômicas e demográficas. Na Alemanha o ensino de Geografia era superior em todos os ramos do saber. Como aponta Veríssimo, secundando e baseando a História, a Geografia havia preparado a unidade alemã e continuava a engrandecer o país como uma das ciências cultivadas com mais predileção nas universidades. Por que não seguimos o modelo de trabalho destes países, adaptando-o à realidade da nossa Geografia Pátria?

\footnotetext{
${ }^{32}$ Os exames até 1889 referiam-se aos chamados Exames Gerais de Preparatórios. A aprovação nos Exames Gerais de Preparatórios, que tinham sido criados na política educacional do Segundo Reinado (1840-1889) no modelado Imperial Collegio de Pedro II, e o bacharelado em Letras do Collegio garantiam a matrícula nos cursos superiores do Império. No regime republicano os Exames de Preparatórios foram substituídos pelos Exames de Madureza, sua aprovação dava o direito ao ingresso em qualquer curso superior de caráter federal, além de çonferir o título de Bacharel em Ciências e Letras (ANDRADE, 1999, p.1-95).

Em função da importância da Escola Politécnica na formação dos então "engenheiros-geógrafos" do século XIX é interessante observar que sua história remonta à história da Escola Central e à história da Academia Real Militar. O Decreto n. 2116, de 1 de maio de 1858, cria a Escola Central e separa o Ensino Militar do ensino de Engenharia Civil. A Academia Real Militar dá, assim, lugar à Escola Central, destinando-se ao ensino das Matemáticas, Ciências Físicas e Naturais e às doutrinas próprias da Engenharia Civil. As matérias essencialmente militares passaram a ficar sob responsabilidade da Escola Militar e de Aplicação do Exército e da Escola Militar da Província de São Pedro do Rio Grande do Sul. A Escola Central passa a oferecer dois cursos, o de Engenharia Civil e o de Engenharia Geográfica, ambos admitindo alunos militares e não-militares. Os militares poderiam dar continuidade aos estudos na Escola Militar e de Aplicação do Exército e os alunos não-militares poderiam obter o diploma de engenheiro geógrafo ou realizar um curso suplementar de engenharia civil na Escola Central, por mais dois anos, e receber o diploma de engenheiro civil. Em 1878 a Escola Central passou a se denominar Escola Politécnica, destinada ao ensino de Engenharia Civil, formando quatro especialistas de engenheiros: engenheiro civil, de minas, geógrafo ou industrial e duas especialidades de bacharéis, em ciências físicas e naturais e em físicas matemáticas. Esses bacharéis tornavam-se, provavelmente, professores de física, química e matemática das escolas secundárias. (Ver CUNHA 1980, p. 94-100 e PEREIRA 1994, p I68-170)
} 
Veríssimo propunha uma reformulação urgente do ensino de Geografia, por intermédio da implantação da Geografia Pátria. Para o autor, não bastava colocar nos programas de ensino o parágrafo Corogafia do Brasil, era preciso programas detalhados inspirados no método moderno do ensino geográfico. Da mesma forma, eram necessários professores capazes e escolas aparelhadas de material didático para que fosse possível estudar tanto a Geografia Física (a formação da natureza do solo, os acidentes geográficos, a hidrografia e o clima) quanto a Geografia Humana do Brasil (os aspectos políticos, econômicos e culturais). Seria também fundamental a implementação de uma política de fiscalização e de incentivo do ensino da Geografia Pátria ${ }^{34}$.

\section{O Gymnasio Nacional e os programas de geografia}

Gymnasio Nacional foi a designação dada entre os anos de 1890 e 1911, décadas iniciais da República, à primeira escola secundária do Brasil - o Imperial Collegio de Pedro $\Pi^{35}$.

\footnotetext{
${ }^{34}$ É interessante observar a proposta de Veríssimo para a implementação de um método moderno de ensino de Geografia. Para o autor o método deveria apresentar a potencialidade de desenvolvimento da formação cívica de um povo. E, nesse sentido, Veríssimo identifica como exemplar o trabalho de um pedagogista francês que ele mesmo viu ser realizado na Alemanha. Guardando as especificidades de tempo e espaço, cabe aqui reproduzir a passagem, destacada por Veríssimo, do trabalho desse pedagogista, pela sua riqueza e atualidade metodológica. principalmente quando se pretende como objetivo do ensino a formação política de um cidadão nacional: "O ensino da geographia começa pela descrição da região onde se acha a escola. O plano da cidade desenrolado diante dos alumnos, é muito circumstanciadamente estudado. As grandes direções que pódem servir á orientação geral, as ruas, as avenidas, em uma palavra, as mais conhecidas arterias da cidade, e a posição relativa da escola, o curso do rio, si algum existe, são primeiramente indicados, sendo tudo apontado por sua vez na carta. Os differentes bairros discriminados por cores especiaes, são successivamente enumerados, desde os mais antigos aos mais novos; recordam os principes que os fundaram, os principaes architectos que on edificaram ou embellezaram com edificios, as circunstancias que thes deu o nome, de forma que assiste-se assim ao progresso que, activo já no antigo nucleo da velha cidade, provocou seu crescimento, fel-a muitas vezes saltar os muros de um recinto fortificado e que, atravez da historia e de suas vicissitudes, desenvolveu-a na forma da cidade moderna em que hoje a vemos. Os nomes das ruas, as pontes, os monumentos publicos servem para de caminho reconstituir una longa chronica local, e em verdade animam aos olhos da criança, os entes d'esta grande morada, da qual é um dos habitantes. Si trata-se de una provincia, da Silesia por exemplo, contam ou repetem os acontecimentos que provocaram a sua reunião á Prusssia. Depois o mestre indica-lhe exactamente as fronteiras. Os alumnos reproduzem immediatamente esta exposição. Mestre e classe estudam após da mesma maneira o curso do rio central, depois o de seus affluentes, depois os productos do solo cuja diversidade é ligada a de outras regiōes da provincia, vindo por fïn a divisão politica d'essa." (DUMESNIL. La Pédagogie dans l'Allemagne du Nord, Paris, 1885. Apud VERÍSSIMO, 1890, p.109-110).

${ }^{35}$ A origem do Imperial Collégio de Pedro II remonta à primeira metade do séc. XVIII, como Abrigo dos Órfãos de São Pedro, obra de caridade da antiga paróquia do mesmo nome de benemerência do Quarto Bispo do Rio de Janeiro, D. Antônio de Guadalupe, que o fundou por Provisão da Câmara Eclesiástica, em 1733. Em 1766 passou a ser designado Seminário de São Joaquim, sendo extinto por Dom João VI, em 1818. Com Dom Pedro I, em 1821, o Seminário é restabelecido, recebendo a nova denominação de Imperial Seminário de São Joaquim. Entretanto acaba sobrevivendo em precárias condições materiais e institucionais. Na Regência, em 1831, o Imperial Seminário de São Joaquim é reformado e entregue à inspeção da Câmara Municipal do Rio de Janeiro. Bernardo Pereira de Vasconcelos converte o Seminário em Colégio de Instrução Secundária, e em 1837, no décimo quinto ano da Independência e em homenagem ao Imperador Dom Pedro II, é criado o Imperial Collegio de Pedro II, sendo inaugurado em 1838 (ANDRADE, 1999, p.7-10). A partir de então e até a proclamação da República o Collegio teria como mecenas e protetor D. Pedro II. Conforme SCHWARCZ (1999, p.150), de orfanato humilde, o "Pedro II" se transformaria na glória do nosso ensino, uma espécie de símbolo de civilidade, de um lado, e pertencimento de uma elite, de outro.
} 
Tanto no Império quanto na República tinha a incumbência de formar a elite sóciopolítica e cultural do país. Seus ex-alunos tornavam-se ministros, senadores, deputados, magistrados, funcionários da alta burocracia, bispos, militares, médicos, escritores, jornalistas e sacerdotes. Seus professores eram renomados intelectuais participantes de expressivas instituições culturais do período, como o Instituto Histórico e Geográfico (1838) e a Associação Brasileira de Letras (1896) ${ }^{36}$. Na virada do século XIX para o século XX, na passagem da Monarquia para a República, era tão ou mais importante que uma escola superior. Era um lugar de sociabilidade intelectual do Rio de Janeiro onde se construíam, se debatiam e se divulgavam os valores nacionais do projeto civilizatório brasileiro.

Criado como padrão da educação oficial no Município da Corte, servindo de modelo para o funcionamento das aulas avulsas, dos liceus e dos estabelecimentos particulares de ensino de todas as províncias, enfim, instituído para ser o "colégiopadrão" do ensino secundário oficial e particular do Brasil Império, o "Pedro II", através dos seus programas de ensino e dos seus livros didáticos, estabelecia a equalização dos conteúdos programáticos e projetava seus métodos pedagógicos e a formação humanística para todas as partes do país.

Mesmo tendo sido idealizado como o padrão de ensino secundário oficial e particular do Império, um modelo elitista que deveria ser esgotado com a República, o "Pedro II" continuou sendo um referencial do ensino brasileiro nas duas primeiras décadas da República. A bandeira republicana que defendia a educação como instrumento central da construção da sociedade moderna, necessitava manter uma instituição com tradição e experiência neste campo. Era esperado do então Gymnasio Nacional o cumprimento do papel educacional republicano, o de controlar a qualidade $\mathrm{e}$ os rumos do ensino secundário e redirecionar o ensino primário brasileiro.

Ao continuar estabelecendo a existência de uma rede oficial de ensino que teria no Distrito Federal seu modelo, a Constituição de 1891 veio, de certa maneira, pelo menos do ponto de vista legal, fortalecer a atribuição do Gymnasio Nacional como "colégio-oficial". Registrado nessa Constituição estava o sistema de equiparação, através do qual os colégios públicos ou particulares de todo o país deveriam não só adotar seus currículos e programas, mas também submeter-se a constante fiscalização do poder central. O "colégio-oficial”, controlado pela ação direta do governo

\footnotetext{
${ }^{36}$ Como parte da elite intelectual dos quadros políticos da Monarquia e da República que passaram pelo Pedro II, podemos citar: Justiniano José da Rocha (professor de História e Geografia e deputado); Antônio Gonçalves Dias (professor de Latim); José Maria da Silva Paranhos (professor de História, senador e ministro do Império); Carlos Laet (professor de Português e diretor do Collegio); Barão de Rio Branco (ex-aluno); Sílvio Romero (professor de Filosofia); João Capistrano de Abreu (professor de História e historiador); Eugenio de Barros Raja Gabaglia (professor de Matemática); Carlos Delgado de Carvalho (professor de Inglês, Geografia e Sociologia); Henrique Toledo Dodsworth Filho (professor de Físico-Química, Diretor do Collegio e Prefeito do Rio de Janeiro); Fernando Antônio Raja Gabaglia (professor de Geografia e Diretor do Collegio) (MARINHO, I. E INNECO, L., 1938). Conforme destaca ANDRADE (1999, p.55), pertencer à época tanto ao IHGB, à ABL ou ao Gymnasio Nacional, como professor catedrático, significava ter seu trabalho intelectual reconhecido e ter seu lugar na história da cultura brasileira.
} 
central, vinha assegurar a preparação para o ensino superior de todo o Brasil e responder pela formação geral do cidadão brasileiro ${ }^{37}$. Tal atribuição acabou colocando em evidência os seus conteúdos programáticos no cenário educacional do país, tornando-os suscetíveis às constantes reavaliações e reformas, provocadas cada vez que novas composições dos interesses políticos nacionais surgiam.

Nesse sentido, os conteúdos programáticos do Gymnasio Nacional adquirem significativa importância como fonte de consulta, pois podem ser vistos como indicadores do estágio do pensamento científico no Brasil daquele momento, assim como do perfil do modelo do novo cidadão republicano que o Estado brasileiro procurava formar. Buscando analisar esse veículo de formação do cidadão nacional, com o objetivo de avaliar o alcance das propostas do ensino da Geografia Pátria defendidas por Veríssimo em A Educação Nacional para a Primeira República, serão examinados a seguir os programas de ensino de Geografia que vigoraram durante as duas primeiras décadas do período republicano. Cabe lembrar que esse também foi o período em que Veríssimo esteve à frente do Gymnasio Nacional, exercendo o cargo de direção entre os anos de 1892 e 1897.

De fato, serão estudados seis programas de Geografia estabelecidos pelas reformas curriculares entre os anos de 1882 e 1912. Optamos por incluir na avaliação o último programa de ensino do período imperial (Programa de 1882) para podermos dispor de um parâmetro comparativo das possíveis mudanças advindas com a República, mudanças estas que deveriam ter sido viabilizadas com a reforma de ensino de 1890. Da mesma forma, também optamos por estender a avaliação dos programas até 1912, quando o Gymnasio Nacional volta à sua denominação de origem, Collegio Pedro II, e perde seu papel de destaque no âmbito do ensino secundário nacional.

Os seis programas de ensino de Geografia do "Pedro II" aqui examinados foram implantados nos seguintes anos: 1882, 1892, 1893, 1895, 1898 e 1912 e tiveram como precedentes reformas curriculares estabelecidas pelo governo central ${ }^{38}$. Como essas reformas buscavam construir o cidadão nacional, era esperado que, pelo menos no plano formal, os novos programas de ensino fixados pela República indicassem uma mudança e/ou uma adequação dos seus conteúdos à nova situação brasileira. Tendo como preocupação central conhecer as novas orientações dadas à época

\footnotetext{
${ }_{38}^{37}$ ANDRADE, 1999, p.53.

${ }^{38}$ Os programas de ensino que serão analisados foram encontrados no Núcleo de Documentação e Memória do Colégio Pedro II (Colégio Pedro II - Centro). Buscando o levantamento desta documentação no Núcleo pudemos encontrar uma publicação contendo a coleção de programas propostos para o ensino público durante 100 anos, entre 1850-1951. Dentre os dezoito programas que compõem esta coletânia, quinze foram elaborados para o "Pedro II". É deste universo que saíram os seis programas de ensino aqui examinados (Ver: VECHIA, Ariclê e LORENZ, Michael Karl 1998). As reformas curriculares estabelecidas pelo governo central foram: Reforma Barão Homem de Mello em 1881, que impulsionou a reforma dos programas de ensino de 1882; Reforma Benjamin Constant de 1890, que promoveu as mudanças dos anos de 1892, 1893 e 1895; Reforma Epitácio Pessoa de 1898 , responsável pelas modificaçōes de 1898; Reforma Rivadávia Correia, responsável pelas mudanças de 1912 (Ver: VECHIA, Ariclê e LORENZ, Michael Karl 1998 e ROCHA, Genylton O. R. da 1996.
} 
para o ensino de Geografia no Brasil, os seis programas serão agora apresentados e avaliados.

No Programa de Ensino de Geografia para o ano de 1882, para o então Imperial Collegio de Pedro II, a cadeira de Geografia era lecionada em quatro anos: no primeiro, no terceiro, no quarto e no sétimo. No primeiro ano, o conteúdo da cadeira denominada Noções de Geografia incluía noções gerais de astronomia, de geodésia, da geografia dos principais países e capitais do mundo e da Geografia Física e Humana do Brasil e do Município Neutro. Dos dez itens apenas três referiam-se ao Brasil. O livro utilizado era Pequena Geografia de Joaquim Maria de Lacerda. No terceiro ano a cadeira denominada Geografia Física incluía noções gerais de astronomia, de geodésia e da Geografia Física do mundo (relevo, clima e vegetação, hidrografia, mares, biologia), focalizando a localização das zonas quentes e o papel do clima sobre a distribuição animal e vegetal na superfície terrestre. À América, sobretudo a Meridional, era dada particular atenção. Os livros adotados eram: Geografia, de P. de Abreu; Atlas, de Delamarche. No quarto ano, na cadeira denominada Geografia e Cosmografia, eram estudadas noções gerais de Geografia Humana (demografia, formas de governo, Estados soberanos, meios soberanos, religião e cultura dos povos), de Geografia Humana das principais cidades do mundo (espaço e posição, população, economia e política) e de cosmografia (noções de astronomia, projeções cartográficas, leis físicas). Os livros utilizados eram: Geografia e Cosmografia, de P. de Abreu; Atlas, de Delamarche. No sétimo ano, a Geografia era tratada na cadeira denominada História e Corografia do Brasil apresentando a Geografia Física (clima, vegetação, hidrografia, relevo, mares, biologia) e humana do Brasil (economia, política, como sistema de governo, administração e instituições do Estado, Constituição do Império e Código Criminal) e das suas províncias. Dos trinta e três itens tratados nesse ano, sete eram dedicados à Geografia Física, cinco à Geografia Humana, vinte às províncias brasileiras e um ao Município Neutro. Os livros adotados eram: Lições de Corografia do Brasil, de Dr. Joaquim Manoel de Macedo; Atlas do Império do Brasil, de Candido Mendes de Almeida.

O Programa de Ensino de Geografia para o ano de 1892, para o então Gymnasio Nacional aparece mais detalhado do que o do ano de 1882. A cadeira de Geografia passa a ser lecionada em cinco anos: no primeiro, no segundo, no terceiro, no quarto e no sétimo. No primeiro ano a cadeira passa a ser denominada Geografia Física (especificamente do Brasil) e Astronomia, contendo informações gerais sobre astronomia, geodésia, cartografia e sobre a Geografia Física do mundo do Brasil. Das suas cinqüenta lições, apenas cinco eram dedicadas ao Brasil e uma à América. $\mathrm{O}$ conteúdo lecionado sobre o Brasil incluía, além de seus aspectos fisiográficos (relevo, hidrografia, vegetação, clima, biologia), as divisões dos limites políticos e a localização das principais cidades. Os livros utilizados eram: Elementos de Geografia Moderna, de Pedro de Abreu; Províncias do Brasil, de Moreira Pinto; Atlas, de Shrader e Anthoine, ed Hachette; Atlas do Brasil, de Lomelino de Carvalho). Nó segundo ano a cadeira denominava-se Geografia e referia-se, basicamente, à Geo- 
grafia Humana do mundo e do Brasil (Geografia Política e Econômica, informações demográficas, culturais e territoriais). Na parte dedicada ao Brasil a ênfase é dada ao estudo de seus estados. Das cinqüenta lições, duas se referiam às noções gerais de Geografia Humana do mundo e duas do Brasil, dez eram dedicadas à corografia dos estados brasileiros, vinte nove à Geografia Humana de diferentes países, sete às noções gerais de astronomia e cartografia. Os livros utilizados eram os mesmos do primeiro ano. No terceiro ano a cadeira denominava apenas Geografia e era dedicada às noções gerais de astronomia, de geodésia, de cartografia e da Geografia Física do mundo do Brasil. Seu conteúdo, a forma de organização das lições e os livros utilizados eram os mesmos do primeiro ano. No quarto ano a cadeira denominada Geografia repetia exatamente o segundo ano, que tratava da Geografia Humana do mundo e do Brasil. Finalmente, no sétimo ano a cadeira denominada Corografia tratava exclusivamente do Brasil. Constituíam seus conteúdos as lições sobre Geografia Física (relevo, hidrografia, vegetação) e humana (espaço e posição, demografia, cultural, econômia e política: agricultura, comércio, meios de transportes, mineração, Constituição Federal) do Brasil e a corografia dos estados brasileiros. Dos quinze itens, sete eram dedicados à Geografia Física, sete à Geografia Humana e um à corografia dos estados. Os livros adotados Átlas do Brasil, de L. de Carvalho; Geografia Física do Brasil, de Wappoeus ${ }^{39}$.

No Programa de Ensino de Geografia para o ano de 1893, a Gẹografia volta, assim como o ano de 1882, a ser lecionada em quatro anos: no primeiro, no segundo, no quarto e no sétimo. No primeiro ano a cadeira denominada Geografia tem como conteúdo principal informações gerais sobre astronomia, geodésia, cartografia e sobre a Geografia Física do mundo do Brasil. De fato, o conteúdo aqui lecionado e os livros adotados eram os mesmos do primeiro ano de 1892 , tendo sido apenas acrescentada uma lição sobre o Brasil, que passava a contar com seis lições sobre um total de quarenta e oito. O mesmo acontecia com o segundo ano. A cadeira era denominada Geografia e tinha como conteúdo básico a Geografia Humana do mundo e do Brasil (Geografia Política e Econômica, informações demográficas, culturais e territoriais). Repetiam-se o conteúdo e os livros de referência do segundo ano de 1892. O quarto ano reproduz o conteúdo do primeiro ano, que por sua vez era o mesmo do terceiro ano de 1892. Com o nome de Geografia, continua a tratar de informações gerais sobre astronomia, geodésia, cartografia e sobre a Geografia Física do mundo do Brasil. Embora não apareça nenhuma indicação de livros, pressupõe-se que eram os mesmos do primeiro ano. No sétimo ano a cadeira denominada Corografia tratava exclusivamente do Brasil, da mesma forma e com a mesma referência bibliográfica do sétimo ano de 1892 .

\footnotetext{
${ }^{39}$ O livro Geografia Física do Brasil, de Wappoeus, publicado em 1871 e traduzido em parte em 1884 , é destacado por Capistrano de Abreu (1904, p.212) e por Alcides Bezerra (1932, p.122) como sendo, indiscutivelmente, o melhor, o mais completo e o mais consicencioso do gênero. Segundo esses autores sua influência foi incontestável mostrando que a Geografia nāo era o simples estudo de memória e um simples catálogo de nomes.
} 
No Programa de Ensino de Geografia do ano de 1895, a cadeira Geografia continua a ser lecionada em quatro anos: no primeiro, no segundo, no terceiro e no sétimo. No primeiro ano a cadeira denominada Geografia trata da Geografia Física e de exercícios de cartografia. O conteúdo trabalhado incluía noções gerais de Geografia Física, de cartografia, assim como de Geografia Física do mundo e do Brasil. Dos trinta e dois itens, apenas oito abordam, especificamente, o Brasil. É interessante observar que o ensino de cartografia é exemplificado através da localização e situação do Gymnasio Nacional na cidade do Rio de Janeiro. O plano e as plantas da cidade constituem material didático aqui utilizado. É empregada uma nova metodologia de trabalho que, partindo de uma escala geográfica reduzida, a sala de aula, chegando a uma escala geográfica maior, a cidade do Rio de Janeiro, parece indicar certa preocupação em veicular, no ensino, um sentimento de pertencimento ao local e uma formação cívica. Essa metodologia pode ser vista como indicativa de modernização do saber geográfico, já tendo sido apontada como importante e inovadora por Veríssimo, em A Educação Nacional ${ }^{40}$. Os livros adotados eram Curso de Geografia, de Lacerda, ou Elementos de Geografia Moderna, de Pedro de Abreu; Curso de Geografia de Moreira Pinto; Atlas do Brasil, de Homem de Mello ou Lomelino de Carvalho; Atlas, de Schrader, Azevedo May ou Delamarche. No segundo ano a cadeira denominada Geografia tem como conteúdo básico a Geografia Humana do mundo. Os temas tratados incluíam tanto noções de Geografia Econômica e Política quanto aspectos culturais, políticos, econômicos e territoriais de diferentes continentes e das principais cidades. Dos quarenta e nove itens, apenas um aborda o Brasil. Os livros são os mesmos do primeiro ano, tendo sido acrescentado Terra Ilustrada, de F.I.C. No terceiro ano a cadeira denominada Geografia do Brasil e Cosmografia trata da Geografia Física (relevo, hidrografia, vegetação, mares, clima) e Humana do Brasil (agricultura, indústria, comércio, meios de transportes, sistemas de governo e administração, demografia), da corografia da Capital Federal e dos estados e de assuntos ligados a cosmografia. Quinze itens são dedicados à Geografia, nove abordam a Geografia Física, cinco, a Geografia Humana e um, o Distrito Federal e os estados brasileiros. Vinte e quatro itens são dedicados à cosmografia (astronomia, geodésia e projeções cartográficas). Os livros utilizados eram: Corografia do Brasil, de H. Martins; Geografia Física do Brasil, de Wappaes; Corografia do Brasil, de Moreira Pinto; Atlas do Brasil, de Homem de Mello ou Lomelino de Carvalho; Carta Física do Brasil, de Homem de Mello; Elementos de Cartografia de F.I.C. No sétimo ano a Geografia era tratada na cadeira, que voltava a ser denominada assim como no último programa do período imperial, de História e Corografia do Brasil. O conteúdo de Geografia estava constituído das mesmas lições e das mesmas referências bibliográficas do sétimo ano de 1892 e de 1893 .

No Programa de Ensino de Geografia para o ano de 1898, a cadeira de Geografia passa a ser lecionada em seis anos: no primeiro, no segundo, no terceiro, no quarto,

${ }^{40}$ Ver nota 34. 
no sexto e no sétimo. No primeiro ano, a cadeira denominada Geografia trata da Geografia Física e de exercícios de cartografia. O conteúdo programático aproximase do desenvolvido no primeiro ano de 1895 . Ocorre, contudo, uma redução no número de itens lecionados, diminuindo a parte dedicada ao Brasil e ao mundo. Esse primeiro ano passa a contar com dezesseis itens. Destes, seis continuam voltados à cartografia, utilizando a mesma metodologia e os mesmos itens do primeiro ano de 1895, nove, à Geografia Física do mundo e um à Geografia Física e à cartografia do Brasil e da América do Sul. Os livros adotados são Geografia Elementar, de Tancredo do Amaral; ou Curso Methodico de Geografia, de Lacerda; ou Lições de Geografia Geral, de Sallaberry (livros novos adotados); ou Curso de Geografia, de Moreira Pinto; Atlas do Brasil de Homem de Mello; Atlas, de Delamarche ou Schrader. No segundo ano de 1898, a cadeira denominada Geografia guarda estreita relação com o segundo ano de 1895; há entretanto uma maior clareza e precisão no conteúdo trabalhado. Trata da Geografia Humana do mundo, utilizando exercícios de cartografia. Os temas vinculam-se à Geografia Política (espaço e posição, população, governo, religião, língua, divisão administrativa, produções, comércio, indústria, vias de comunicação e cidades principais) dos países. Dos quarenta e quatro itens, um apenas aborda o Brasil, dez abordam as Repúblicas da América Latina e 33, outros países. Os livros utilizados são os mesmos do primeiro ano. No terceiro ano a cadeira denominada Geografia do Brasil passa a tratar apenas da Geografia Física e Humana do Brasil, se diferenciando da cadeira lecionada no terceiro ano de 1895 , que conjugava assuntos de cosmografia. A parte dedicada ao Brasil continua possuindo as mesmas lições do ano de 1895, tendo sido retirado apenas um item de Geografia Humana. São quatorze itens lecionados; destes, nove são de Geografia Física e cinco de Geografia Humana do Brasil. Da bibliografia utilizada, três livros que eram utilizados em 1895 permaneceram como referência livros: Corografia do Brasil, de H. Martins; Atlas do Brasil, de Homem de Mello ou Lomelino de Carvalho; Carta Física do Brasil, de Homem de Mello. No quarto ano a cadeira denominada Geografia era dedicada a noções de cosmografia e surge como fruto da separação do conteúdo dado no terceiro ano de 1895 e eram lecionados dezessete itens. A bibliografia utilizada era Cosmografia, de F.I.C. ou Elementos de Cosmografia, de Henrique Martins. No sexto ano não aparece detalhado o conteúdo trabalhado na cadeira denominada Geografia apenas a orientação para recapitulação da Geografia da América, especialmente do Brasil. O mesmo ocorre com relação à cadeira denominada Geografia lecionada no sétimo ano, sendo somente indicado, como conteúdo, a recapitulação geral da Geografia, especialmente a do Brasil, e como bibliografia, os livros utilizados no segundo e terceiro anos.

No Programa de Ensino de Geografia para o ano de 1912, para o então Collegio Pedro II, a cadeira de Geografia passa a constar apenas em três séries: na primeira, na segunda e na terceira. Na primeira série a cadeira denominada Geografia trata basicamente da Geografia Física do mundo (relevo, vegetação, hidrografia, mares, clima) e de algumas noções de astronomia. Ao todo são vinte e quatro itens, entre- 
tanto somente um aborda o Brasil, a Geografia Física brasileira. Na segunda série a cadeira denominada Geografia discorre especificamente sobre a Geografia Humana do mundo, com itens dedicados, pela primeira vez, às noções históricas e geográficas de países. Dos trinta e oito itens trabalhados nenhum deles é dedicado ao Brasil. Na terceira série é finalmente dada exclusiva atenção à realidade brasileira. A cadeira denominada Geografia apresenta a Geografia Humana e Física do Brasil, contendo também algumas lições de cosmografias. Dos trinta e cinco itens, onze tratam da corografia dos estados brasileiros (situação, superfície, limites, aspectos físicos, clima, salubridade, orografia, hidrografia, história e governos), nove da Geografia Humana do Brasil (economia e cultura), dois da Geografia Física do Brasil (clima, relevo, vegetação), doze de noções de cosmografia e um de cartografia. Não constam, em nenhuma dessas séries, referências a livros textos utilizados.

\section{Programas de geografia: uma análise à luz das propostas de Veríssimo}

A partir da detalhada apresentação dos programas de Geografia do Gymnasio Nacional, acima exposta, algumas inferências podem ser tecidas com rẹlação à forma e ao conteúdo do ensino de Geografia. Comparando o último programa de ensino do Império, o Programa de 1882, com o primeiro da República, o Programa de 1892, nota-se, neste, um aumento não apenas do número de anos em que a Geografia passa a ser lecionada, mas também das lições dedicadas ao Brasil. Todas as matérias remetem para a Geografia Física e Humana brasileira, sendo mantida uma cadeira dedicada exclusivamente ao Brasil. O conteúdo aparece um pouco menos enciclopédico e mais definido, destacando-se, na parte humana da Geografia, da mesma forma que no Programa de 1882, temas políticos gerais e políticos do Brasil. Interessante observar também que no programa do Império o clima aparece como um elemento explicativo da distribuição animal e vegetal na superfície terrestre, indicando a influência das teorias deterministas, típicas do final do século XIX, situação que não mais se registra nos programas da República aqui analisados. Em ambos os programas a Geografia Física e as lições de cosmografia recebem grande atenção, possivelmente em função da influência do curso de engenharia da Escola Politécnica, da qual saíam grande parte dos professores das escolas secundárias. Os livros adotados não são os mesmos de 1882.

O Programa de 1893 dá continuidade às propostas do Programa de 1892. A única mudança que cabe ser mencionada é a retirada da cadeira de Geografia do quarto ano, Geografia Humana do mundo e do Brasil, embora o conteúdo dedicado ao Brasil aqui não fosse expressivo.

O Programa de 1895, embora não destoe do de 1893, e portanto do de 1892 , apresenta duas situações novas, tonando-se singular no universo analisado. A primeira é a introdução de uma nova metodologia de trabalho no uso da cartografia, 
possível de potencializar o desenvolvimento da formação política de um cidadão, uma vez que, conforme já apontado, veicula o sentimento de pertencimento à nação. Talvez a introdução desta metodologia tenha sido fruto do trabalho de Veríssimo na ocasião em que esteve à frente do Gymnásio Nacional, visto que em A Educação Nacional o autor faz destaque a essa metodologia, como forma de modernização do ensino e de construção cívica da nação. A segunda situação nova no Programa de 1895 refere-se ao retorno dos livros utilizados no último programa do período imperial. Esses passam a ser associados às novas bibliografias, indicando a carência de boas literaturas ou mesmo a qualidade dos compêndios e livros do período imperial, comparados com os do período republicano.

O Programa de 1898, o último programa que irá reger a Geografia do Gymnasio Nacional, reproduz o mesmo conteúdo do Programa de 1895. Conta também com a utilização da metodologia de trabalho de 1895 e com a associação de literaturas novas e antigas. Registra-se o aumento de mais duas cadeiras. Uma delas foi resultado da separação da Geografia do Brasil e da Cosmografia, que passa a tratar exclusivamente da cosmografia, e a outra surge apenas com uma breve indicação para recapitulação da Geografia da América, especialmente do Brasil, não discriminando seu conteúdo programático.

No Programa de 1912, do então Collegio Pedro II, não mais aparece a metodologia de trabalho dos anos de 1895 e 1898 , havendo também diminuição dọs temas vinculados à cosmografia. É curioso notar que pela primeira vez surgem lições sobre noções histórico-geográficas dos países e do Brasil. Entretanto, observa-se o enxugamento d $乞$ conteúdo programático, que se apresenta com maior clareza e delimitação, mas que perde a riqueza, no plano político-cultural, existente nos outros programas examinados. De fato, o ano de 1912 apresenta uma redução do número de cadeiras de Geografia e do conteúdo programático dedicado à Geografia brasileira, especialmente à humana e política, que se fazia presente nos Programas anteriores analisados.

Embora os programas de Geografia do Gymnasio Nacional não apresentem uma ruptura com o modelo anterior de ensino, não demonstrando, por conseguinte, uma mudança verdadeiramente radical e uma nova orientação, conforme pregava e desejava Veríssimo em A Educação Nacional, houve algumas modificações que foram promovidas pelas novas orientações do regime republicano através das reformas curriculares implementadas. Entretanto, é possível que para a efetivação dessas modificações, a atuação política e intelectual de Veríssimo tenha sido importante, uma vez que, no período de 1892 a 1898, esteve na direção dessa instituição de ensino. Fato que pode vir também contribuir para essa inferência é o programa de Geografia de 1912, que, conforme visto, é qualitativa e quantitativamente inferior aos demais analisados reduzindo as possibilidades de efetivação de uma Geografia Pátria.

JOSÉ VERÍSSIMO E A PROPOSTA DA GEOGRAFIA PÁTRIA NA PRIMEIRA REPÚBLICA BRASILEIRA VISTA ATRAVÉS DOS PROGRAMAS DE GEOGRAFIA DO GYMNASIO NACIONAL

Resumo: O trabalho ora proposto tem como fonte de estudo a obra de um dos mais importantes 
intelectuais do final do século XIX, o crítico literário José Veríssimo Dias de Matos - A Educação Nacional. Publicada em 1890, primeiro ano do regime republicano, foi a mais representativa e importante obra da vertente pedagógica do autor. Será analisada a proposta de implantação da Geografia Pátria para a Primeira República brasileira, apresentada por Veríssimo em A Educação Nacional e investigada sua repercussão no contexto nacional, entre os anos de 1892 e 1912, através do exame dos conteúdos programáticos ministrados no Gymnasio Nacional, estabelecimento padrão de ensino oficial no Brasil à época. Para tanto, o trabalho está dividido em quatro partes. Na primeira, utilizando informações "biobibliográficas", procura-se apresentar a importância intelectual de José Veríssimo, situando-o no cenário cultural brasileiro da época. A segunda parte é dedicada à apresentação da Educação Nacional e da Geografia Pátria. A terceira, ao Gymnasio Nacional e aos programas de geografia. E, por fim, a quarta parte é dedicada à análise desses programas à luz das propostas de Veríssimo.

Palavras-chave: Historia da Geografia, Geografia Brasileira, Geografia Nacional, Educação Nacional, Gymnasio Nacional.

JOSE VERISSIMO AND HIS PROPOSAL TO CREATE A NATION GEOGRAPHY DURING THE BRAZILIAN FIRST REPUBLIC PERIOD THROUGH THE EYES OF THE GEOGRAPHY PROGRAMME FOR THE NATIONAL LOWER SECONDARY SCHOOLS

Abstract: This study is based on the essay written by one of the most important scholar of the end of the XIX century, the book critic José Veríssimo de Dias de Matos - "A Educação Nacional" (National Education). This essay, published in 1890, the first year of the republican rule in Brazil, was the most representative and important from the author's pedagogical works. This study aims basically to analyze the proposal for implementation of the Nation Geography during the Brazilian First Republic, presented by Veríssimo in "A Educação Nacional" and investigate the proposal repercussion in the country context between 1892 and 1912, through the examination of the contents of the National Lower Secondary School Program, which was Brazil official education standard at that time. The study is divided in four parts. In the first part, using "biobibliographical" information, I emphasize the intellectual importance of Jose Veríssimo as well as his role in that period Brazilian cultural scene. The second part is dedicated to introduce National Education and Nation Geography. In the third, I discuss the National Lower Secondary School and the geography programs. Finally, in the fourth part, I analyze these programs in view of Verissimo's proposals.

Keywords: History of Geography, Brazilian Geography, Nation Geography, Nacional Education, Gymnasio Nacional.

\section{BIBLIOGRAFIA}

ANDRADE, Vera Lucia C. de Queiroz. 1999. Colégio Pedro II: um lugar de memória. Orientação: Eliane Garcindo de Sá. Rio de Janeiro. Tese (Doutorado em História Social). Universidade Federal do Rio de Janeiro.

ABREU, Capistrano de. 1904. A geografia do Brasil. In: Almanaque Brasileiro Garnier, Rio de Janeiro, anno 2.

BARBOSA, Alexandre João. 2001. José Veríssimo: História da Literatura Brasileira. In: MOTA, Lourenço Dantas. Introdução ao Brasil: um banquete no trópico 2. São Paulo: editora SENAC. p.279-297. . 1985. A Vertente Pedagógica. In: Veríssimo, José. A Educação Nacional. Porto Alegre: Mercado Aberto. 
BEZERRA, Alcides. 1932. A geografia do Brasil no século XIX. In: Revista da Sociedade de Geografia do Rio de Janeiro. Tomo XXXVI. 2 semestre, p.115-43. BOSI, Alfredo. 1994. História concisa da literatura brasileira. São Paulo: Editora Cultrix.

CARVALHO, José Murilo. 1999a. Brasil: nações imaginadas. In: Pontos e Bordados. Belo Horizonte: Editora UFMG. p.233-268. 1999b. Os bestializados: o Rio de Janeiro e a República que não foi. Companhia das Letras. São Paulo: Companhia das Letras. 1999c. Bernardo Pereira de Vasconcelos. São Paulo: Ed 34.

CAVAZOTTI, Maria Auxiliadora.1999. José Dias de Matos Veríssimo. In: FÁVERO, Maria de Lourdes e BRITO, Jader de Medeiros. Dicionários de educadores no Brasil. Rio de Janeiro: Editora UFRJ/ MEC-Inep.

CUNHA, Luiz Antônio. 1980. A universidade temporã: o ensino superior da colônia à Era de Vargas. Rio de Janeiro: Editora Civilização Brasileira.

LEMOS, Renato L. do C. N. E. 1997. Benjamin Constant: biografia e explicação histórica. Revista Estudos Históricos. n.19 (Indivíduo, biografia, história) Rio de Janeiro: FGV.

LEVASSEUR, E. 2000 (1989). O Brasil. Rio de Janeiro: Bom Texto Letras \& Expressões. 1 edição brasileira.

MORAES, Antônio C. Robert. 1988. Ideologias geográficas. Espaço Política e Cultura no Brasil. São Paulo: Hucitec.

1991. Notas sobre identidade nacional $e$ Institucionalização da Geografia no Brasil. Revista Estudos Históricos. n.8 (História e Natureza) Rio de Janeiro: FGV.

1999. História social da geografia no Brasil: Elementos para uma agenda de pesquisa. In: Anais do I Encontro Nacional de História do Pensamento Geográfico. Unesp - Rio Claro. p.17-23.

OLIVEIRA, José Deusdedete. 1993. O Ensino de História no Colégio Pedro II: uma leitura dos programas de ensino e de exame até o final do século XIX. Orientação: Nilda Alves. Rio de Janeiro: UFF. (Dissertação de Mestrado em Educação) NAGLE, Jorge. 1997. A Educação na Primeira República. In: Boris Fausto (org.) História Geral da Civilização Brasileira, tomo III, vol. 2. São Paulo:Difel. p.259291.

NEEDELL, Jeffrey 1987. D. Belle Époque tropical: sociedade e cultura de elite no Rio de Janeiro na virada do século. São Paulo: Companhia das Letras.

PEREIRA, Potiguara. 1994. Engenharia militar. In: VARGAS, Milton (org.). História da técnica e da tecnologia no Brasil. São Paulo: UNESP: Centro Estadual de Educação Tecnológica Paula Souza. p. 163-178.

ROCHA, Genylton O. R. 1996. A trajetória da disciplina geografia no currículo escolar brasileiro (1837-1942). Orientador: Ana Maria Saul. São Paulo: PUC.' Dissertação (Mestrado em Educação) 
SCHWARCZ, Lilia Moritz. 1999. As Barbas do Imperador: D. Pedro II, um monarca nos trópicos. São Paulo: Companhia das Letras.

SCHWARCZ, Lilia M. 1995. O espetáculo das raças: cientistas, instituições e questão racial no Brasil, 1870-1930. São Paulo: Cia das Letras.

SEGISMUNDO, Fernando. 1966. Do jardim à universidade. Rio de Janeiro: Fundo Universal de Cultura.

SEVCENKO, Nicolau. 1999. Tensões sociais e criação cultural na Primeira República. São Paulo: Brasiliense.

VERÍSSIMO, José. 1970. Estudos amazônicos. Coleção Amazônica, Série José Veríssimo. Universidade Federal do Pará. . 1906. A educação nacional. Rio de Janeiro: Francisco Alves. 1890. A educação nacional. Rio de Janeiro: Francisco Alves. Pará: Editores Tavares \& C $C^{\text {a }}$ Livraria Universal.

VECHIA, Ariclê e LORENZ, Michael Karl. 1998. Programa de ensino da escola secundária brasileira 1850-1951. Curitiba: Ed do Autor. 